\title{
THE FORECASTING OF VOLUMES OF FOREIGN CURRENCY LOANS GRANTED TO INDIVIDUAL ENTREPRENEURS IN POLAND IN THE ASPECTS OF ECONOMIC SECURITY
}

\section{Original article}

Accepted: September 2020

Published: November 2020

Peer review:

Double blind

Keywords:

foreign currency loan, forecasting

This work is licensed under the Creative Commons AttributionNonCommercial-NoDerivatives 4.0 License

\author{
Bartosz Kozicki ${ }^{1}$ \\ ORCID: 0000-0001-6089-952x \\ Paweł Jaśkiewicz ${ }^{2}$ \\ ORCID: 0000-0002-8863-6948
}

Military University of Technology in Warsaw, gen. Sylwestra Kaliskiego 2, 01-476 Warszawa

\begin{abstract}
In the article, the author raises the issue of the forecast of volumes of foreign currency loans granted in Poland to individual entrepreneurs on the basis of original data gathered from the National Bank of Poland, in the aspects of economic security. The research was initiated with the analysis and evaluation of time series within the volumes of foreign currency loans in Poland for individual entrepreneurs between 2012 and 2017. An outlier was detected and it was changed to the arithmetic mean of an element from the previous series and the following one. Then, the analyzed series was divided into two parts. As a result of the assessment made, forecasting was carried out, with the use of various methods, of the first part of an isolated time series composed of 60 elements and, after that, the best prognostic method was selected. Based on this method, the forecasting of the original time series was made for $2018-12$ prospective periods.
\end{abstract}

\footnotetext{
${ }^{1} \mathrm{PhD} \mathrm{n}$ the field of economic sciences, the discipline of management sciences. He works as an assistant professor at the Faculty of Security, Logistics and Management at the Military University of Technology. Research interests focus on economic and financial issues of the enterprise, taking into account the scientific discipline of management and security. E-mail: bartosz.kozicki@wat.edu.pl.

${ }^{2}$ Employee of the International Cooperation Department of the Military University of Technology. His interests revolve around financial markets and their dynamic changes. E-mail: pawel.jaskiewicz@wat.edu.pl.
} 


\section{Introduction}

A loan means a specific form of agreement. For economic reasons, this term is restricted only to the credit (cash) granted by banking institutions.

As a result of literature analysis and the authors' experience, it is clear that different prognostic methods are implemented by institutions dealing with the forecasting of foreign currency loans, and these methods do not always seem accurate. Therefore, this situation became a premise for undertaking research related to the use of correct prognostic methods suitable for the forecasting of foreign currency loans for individual entrepreneurs in Poland.

The research question is centered around the choice of the methods for the forecasting of foreign currency loans for individual entrepreneurs in Poland in order to optimize the forecast of the achieved results. The authors of this study formulated the following main research question: Will the application of an analysis and evaluation of time series of foreign currency loans for individual entrepreneurs in Poland retrospectively allow the choice of an optimum prognostic method and the execution of this forecast?

Literature on the question of forecasting is very extensive and scattered. What it lacks is precise descriptions of the means of analysis and evaluation of time series retrospectively, the construction of prognostic models and the courses of action in order to calculate the forecast result. From the point of view of this study, the most useful literature dealing with forecasting is included in the bibliography. According to the authors, they are insufficient in order to conduct a detailed analysis and evaluation of the considered time series related to the volumes of foreign currency loans granted in Poland to individual entrepreneurs in millions between 2012 and 2017. The analysis and evaluation, which are correctly conducted, and the prognostic model constructed on the basis of them require, additionally, intuition and experience with such research.

The main purpose of this study is an attempt to conduct the forecast for the next year - twelve periods in the aspect of economic security. The research span is 2012-2017, whereas the research area is the region where banks operate in Poland.

The subject of research is banks, whereas the object of research is foreign currency loans for individual entrepreneurs in Poland.

The research methods applied in the article were the analysis of literature dealing with issues related to foreign currency loans, forecasting, analysis of source texts, computer simulation method and comparison. Additionally, the research technique in the form of the Statistica computer program was used. What is more, the following research tools were 
applied: quartile graph, autocorrelation, partial autocorrelation, multiple regression analysis, bar chart, Shapiro-Wilk test, Grubbs' test.

The article was composed of the introduction, three substantive points, a summary and conclusions.

\section{Literature review}

A foreign currency loan is a specific type of credit granted in a currency that is different from the borrower's national currency. Concluding a credit agreement, the credit recipient anticipates lower interest rates than the ones he/she can get in their own country in the national currency. Such a decision involves currency risk, which may cause the increase of the amounts due created by changes in the exchange rates, which can be triggered by various factors (Araten, Jacobs and Varshney, 2004). One of the these factors could be, for instance, the quantity of particular currency loans taken out worldwide. From the point of view of banks, the analysis and evaluation of the quantities and volumes of foreign currency loans are extremely significant, because they ensure economic security. In literature, economic security means a state of reality in which it is possible to harmoniously develop the economy and ensure a proper standard of living for citizens through uninterrupted access to raw materials, sales markets and capital (Nurzyńska, 2016). The analysis and evaluation, conducted correctly, will allow us to choose prognostic methods and carry out forecasting.

Forecasting is a reasonable and scientific way of anticipating future events. On the other hand, the purpose of forecasting is to reduce the risk for fear of making a mistake (Asarnow and Edwards, 1995). This is of great significance during the planning of required reserve ratios applicable within the Central Bank.

The literature raises various classifications of forecasting methods, but the most commonly selected one is the division into quantitative and qualitative methods. For the purpose of this article, qualitative methods will be applied. The choice of appropriate methods will be preceded by the precise analysis and evaluation of time series within the volumes of foreign currency loans in Poland for individual entrepreneurs between 2012 and 2017 in millions on a monthly basis and retrospectively. 


\section{Data analysis}

\subsection{Analysis of time series}

Figure 1 juxtaposes the data related to the amount of foreign currency loans in millions PLN granted to individual entrepreneurs between 2012 and 2017 on a monthly basis. The information was obtained from the website of the National Bank of Poland.

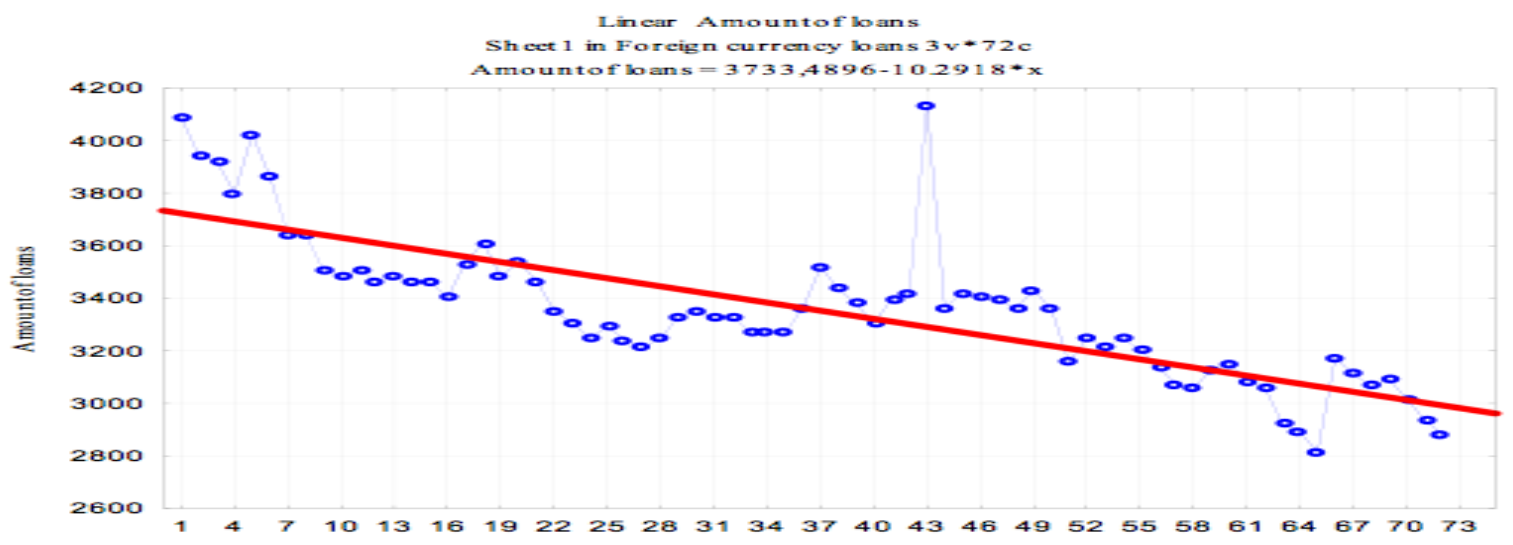

Figure 1. Juxtaposition of the data related to the amount of foreign currency loans in millions PLN granted to individual entrepreneurs between 2012 and 2017 and outlining the trend line.

Source: Narodowy Bank Polski (2018). Available at:

https://www.nbp.pl/home.aspx?f=/statystyka/pieniezna i bankowa/nal zobow.html.

From the visual assessment of Figure 1, it can be inferred that there is a downward trend. The trend line was drawn in Figure 1 with a red line, and it was described with the function $Y=3733,4896-10,2918 \bullet x$. The alpha of this function indicates the declining trend. From the visual assessment of the graph, the $43^{\text {rd }}$ element of the time series can be considered to be an outlier of a haphazard nature.

\subsection{Analysis of outliers}

In order to examine if there are outliers and extreme values in a selected series, Grubbs' test and the diagram-box were applied (Figure 2). 


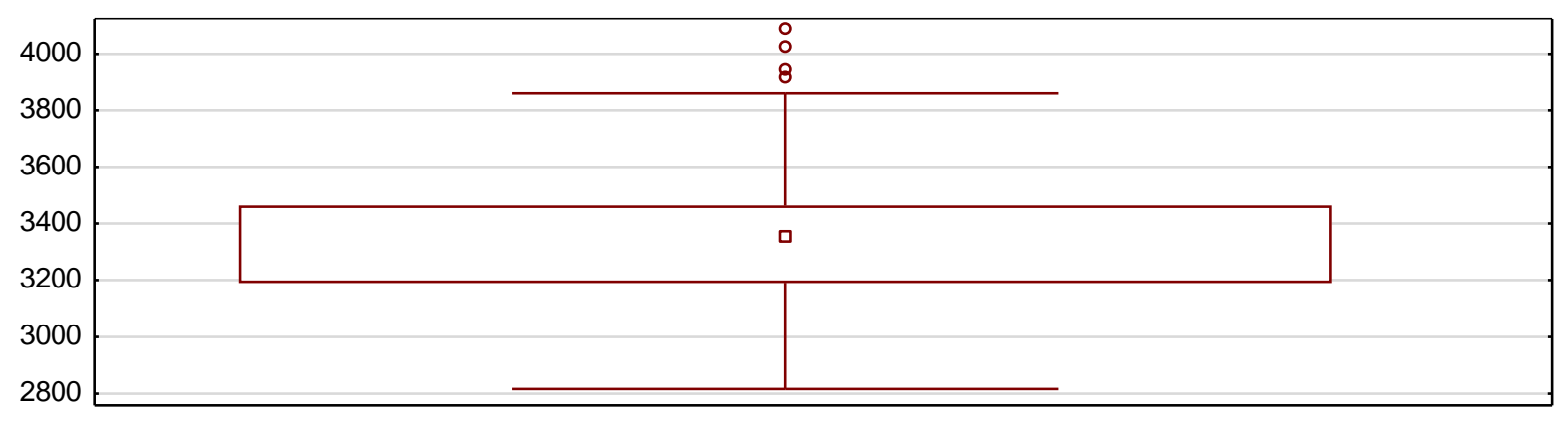

\begin{tabular}{|c|c|c|c|c|c|c|c|}
\hline & N & $\begin{array}{c}\text { Arithmetic } \\
\text { average }\end{array}$ & Grubbsa & P value & Min & Max & $\begin{array}{c}\text { Standard } \\
\text { deviation }\end{array}$ \\
\hline $\begin{array}{c}\text { Loans } \\
\text { amount }\end{array}$ & 72 & 3357,84 & 2,82 & 0,27 & 2816,30 & 4129,48 & 273,56 \\
\hline
\end{tabular}

Figure 2. Juxtaposition of the diagram-box and Grubbs' test.

Source: own elaboration.

The presence of outliers was confirmed by Grubbs' test and Tukey's test, outlined in the diagram-box. The extreme values are the following positions of the analyzed time series: 1. - 4089,794., 2. - 3943,386., 3. - 3922,144., 5. - 4023,344. and 43. - 4129,482.. From the point of view of future forecasting, a critical position of the analyzed time series after visual assessment is 43. For research purposes and in order to obtain better forecast results, after visual assessment of the graph, one extreme value in the position 43. - 4129,482 was altered, turning it into the arithmetic mean of an element from the time series of the $42^{\text {nd }}$ period and the following $44^{\text {th }}$ period $-3393,861$.

The time series after the alteration of the extreme value in position 43 is presented in the figure below.

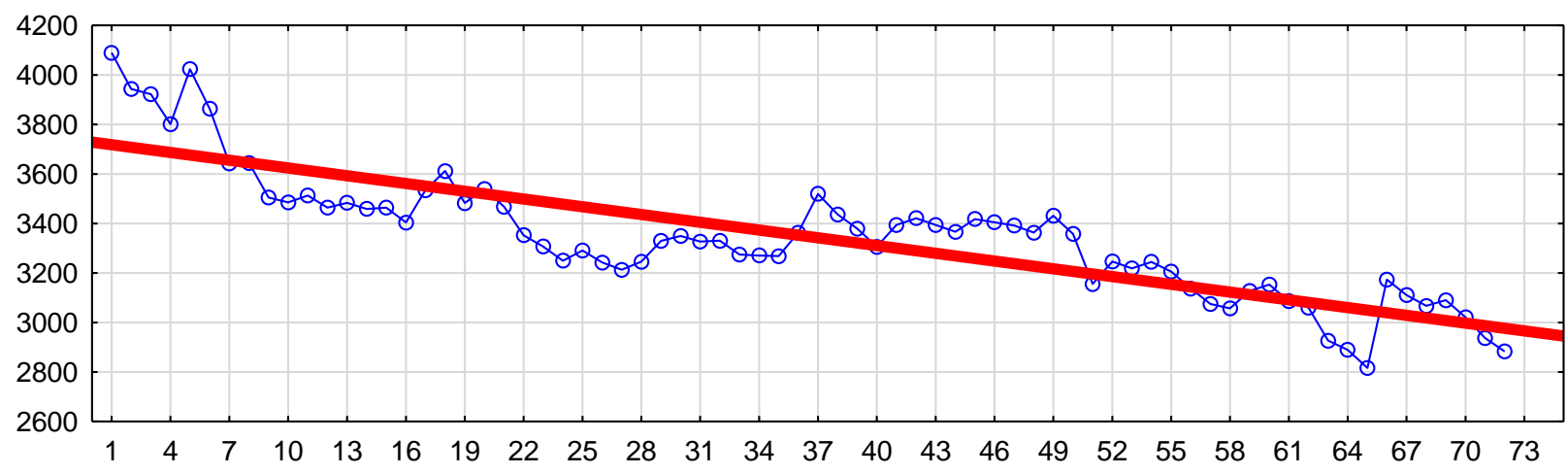

Figure 3. Juxtaposition of the data related to the amount of foreign currency loans in millions PLN granted to individual entrepreneurs between 2012 and 2017 after the alteration of an extreme value in position 43 of the selected time series, and the outline of the trend line.

Source: own elaboration. 


\subsection{Detailed analysis of time series}

Afterwards, the analysis of the selected time series was conducted with the application of the following research tools: autocorrelation, partial autocorrelation, bar chart, ShapiroWilk test (Figure 4.).
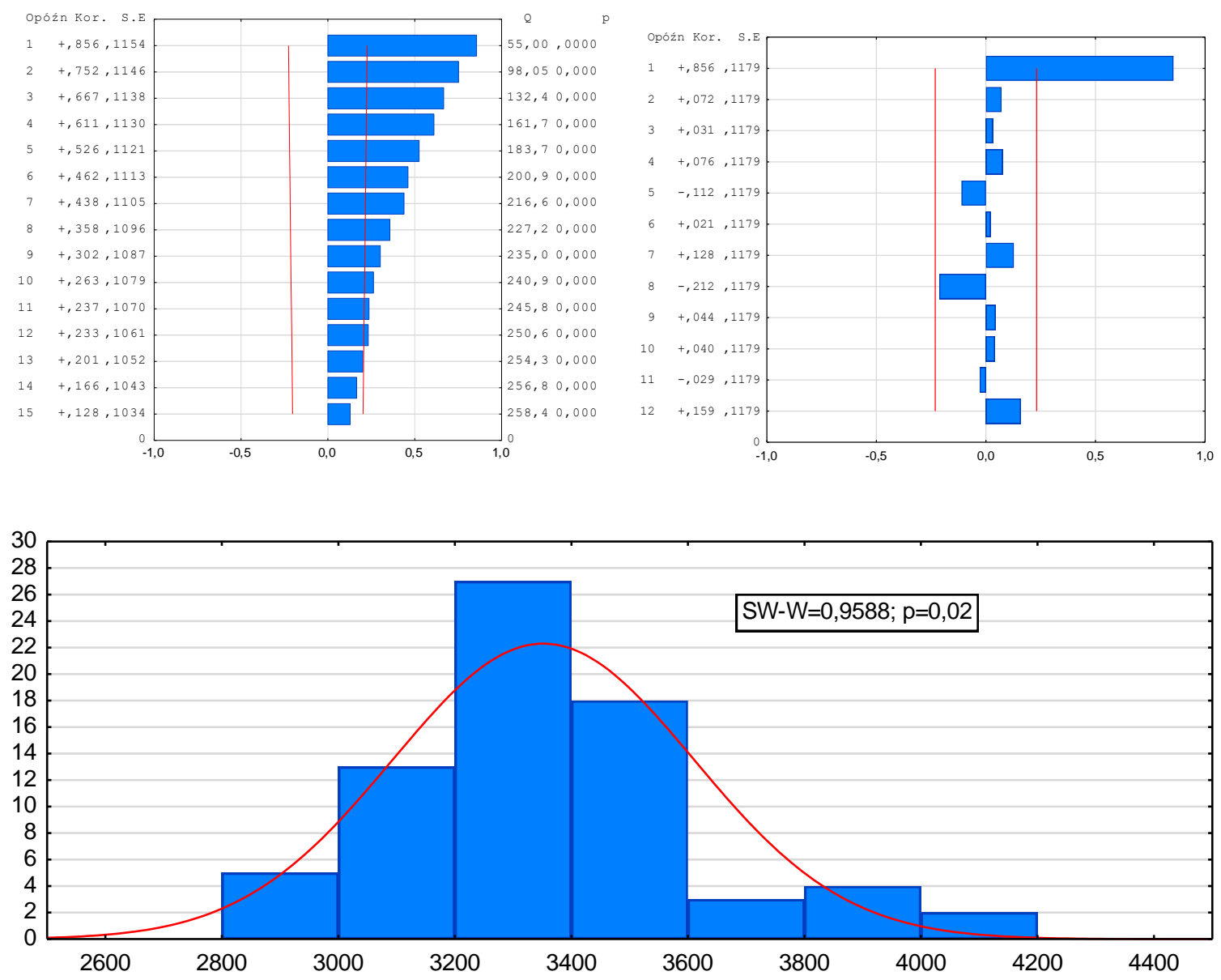

Figure 4. Application of research tools: autocorrelation, partial autocorrelation, bar chart, Shapiro-Wilk test.

Source: own elaboration.

The application of autocorrelation indicates that the most visible autocorrelation takes place for the first lag, and it equals 0,856. Autocorrelations for the consecutive lags become smaller and smaller and finally reach zero. In case of partial autocorrelation, it was the first lag only, which equalled 0.856 , that became crucial at the 0,05 significance level. The above figure indicates that the partial autocorrelation function is cut off for $\mathrm{k} \geq 2$. The distribution of the series presented in the bar chart points to its normality, which was corroborated with the Shapiro-Wilk test. 


\subsection{The construction of the multiple regression analysis}

Subsequently, for research purposes, a multiple regression binary model was constructed in order to investigate the existence of a trend and seasonality (fig. 5).

\begin{tabular}{|c|c|c|c|c|c|c|}
\hline \multirow[b]{2}{*}{$\mathrm{N}=72$} & \multicolumn{6}{|c|}{$\begin{array}{l}\text { Summary of dependent variable regression: } \\
R=, 92287539 R^{\wedge} 2=, 85169899 \text { Correction. } R 2=, 84284519 \\
F(4,67)=96,196 p<0,0000 \text { Standard error of estimation: } 102,121\end{array}$} \\
\hline & $\mathbf{b}^{\star}$ & $\begin{array}{c}\text { St Error } \\
z b^{*}\end{array}$ & $\mathrm{~b}$ & $\begin{array}{c}\text { St Error } \\
\mathrm{z} b\end{array}$ & $t(67)$ & $p$ \\
\hline Empty & & & 4214,664 & 71,88272 & 58,63250 & 0,000000 \\
\hline June & $\overline{0,11916}$ & 0,047076 & 110,284 & 43,57047 & 2,53117 & 0,013722 \\
\hline $\mathrm{t}$ & 1,81133 & 0,481567 & 22,295 & 5,92746 & 3,76133 & 0,000358 \\
\hline$t^{\wedge} 2$ & $-1,49548$ & 0,336775 & $-0,244$ & 0,05503 & $-4,44058$ & 0,000034 \\
\hline Int & $-1,34192$ & 0,192100 & $-379,287$ & 54,29607 & $-6,98553$ & 0,000000 \\
\hline
\end{tabular}

Figure 5. Construction and application of a multiple regression model for the evaluation of the existence of a trend and seasonality.

Source: own elaboration.

Figure 5 presents only crucial predictors which indicate the existence of a trend $\left(\mathrm{t}, \mathrm{t}^{2}, \operatorname{lnt}\right)$ and seasonality (June). Then, the remainder of the constructed model was examined. (Fig. 6).
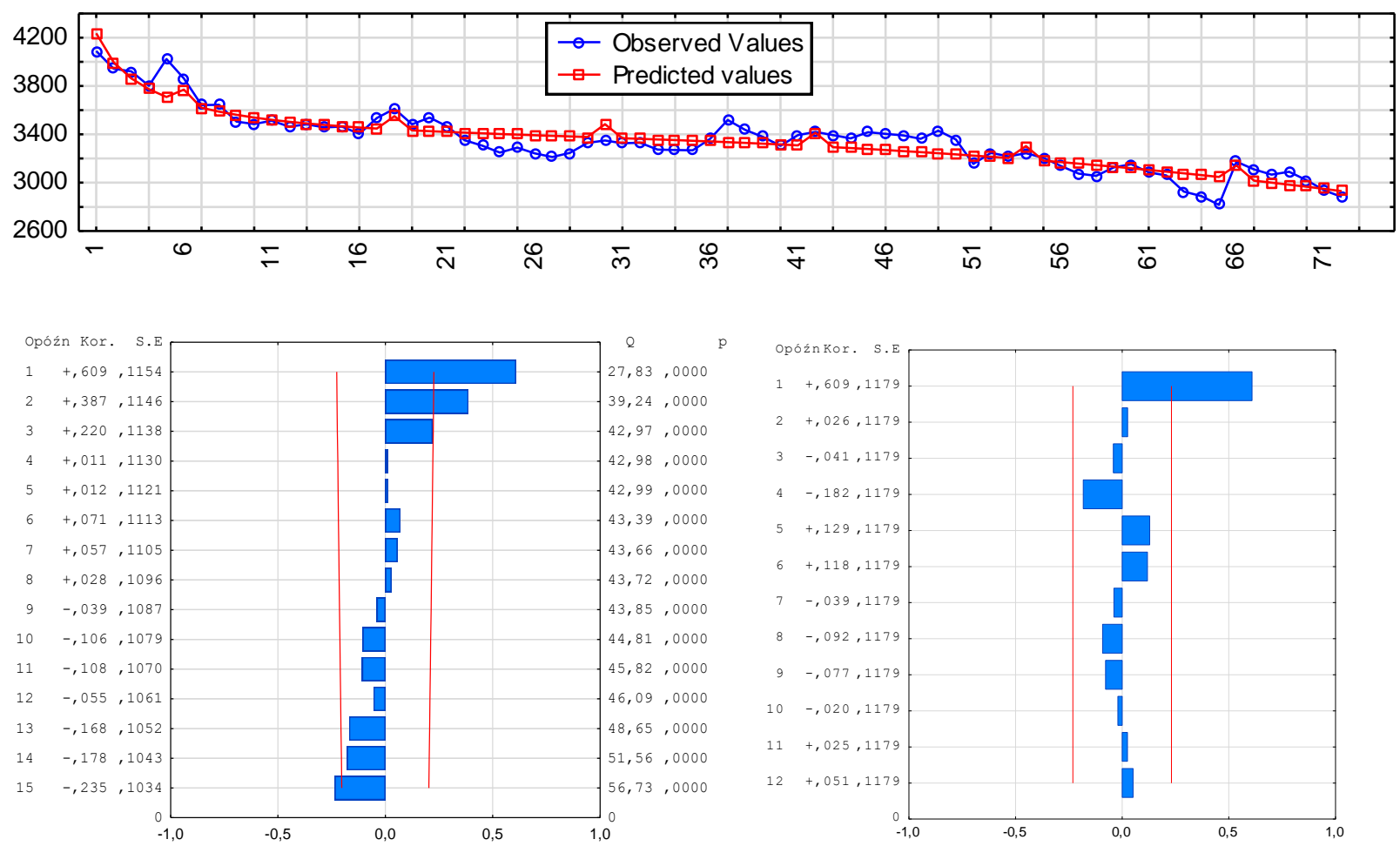

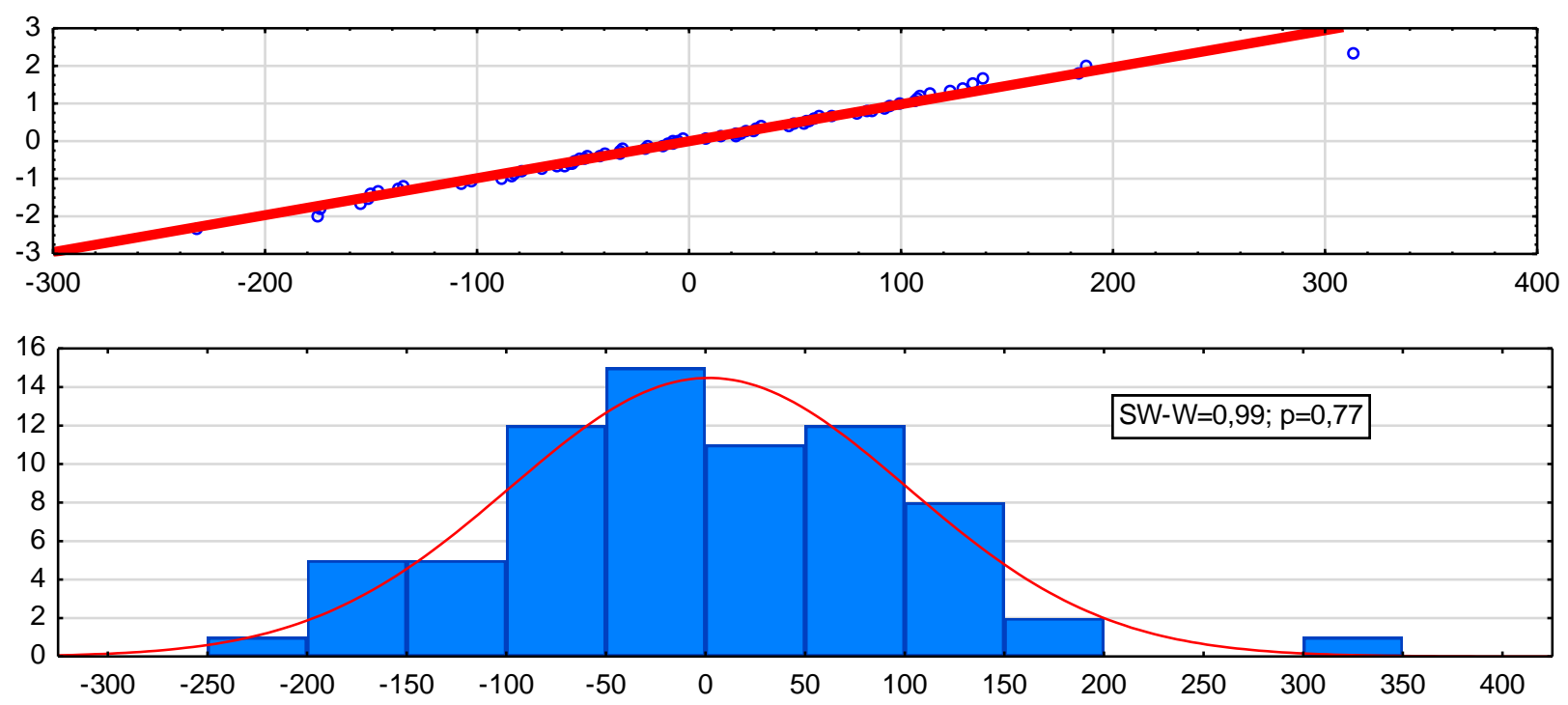

Figure 6. Evaluation of the remainder of the constructed multiple regression model with the application of research tools, such as: line graph of anticipated and observed values, autocorrelation, partial autocorrelation, normality graph, bar chart, Shapiro-Wilk test.

Source: own elaboration.

In Figure 6, it can be noticed that there is a close match between the anticipated and observed values. The autocorrelation is decreasing slowly. The first and second lags are of crucial importance. On the other hand, the partial autocorrelation is cut off for lags greater than 1 . The bar chart indicates the distribution, which is very similar to a normal one. On the other hand, the normality graph shows that all quantiles are placed along the straight line, so they have a distribution approximate to a normal distribution. The normality of the remainder of the constructed model is also corroborated with the Shapiro-Wilk test (Fig. 6).

Thereafter, for analytical purposes, the selected time series was divided into two parts. On the basis of the first one, the forecasting in the third substantive point was conducted. However, the evaluation of the conducted forecasting was made in accordance with the second part of the selected time series (Fig. 7). 


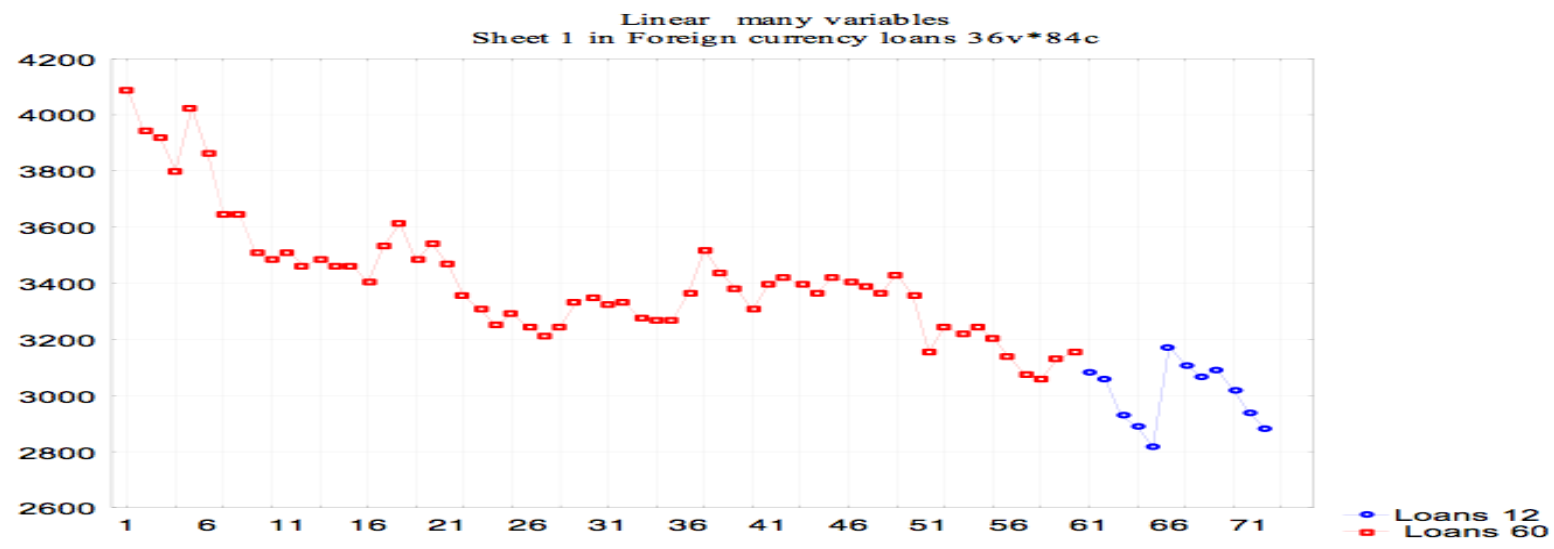

Figure 7. Division of retrospective data concerning the amount of foreign currency loans in millions PLN granted to individual entrepreneurs between 2012 and 2017 into two periods comprised of 60 and 12 elements.

Source: own elaboration.

\section{Testing the forecasting models}

Winters' additive exponential smoothing was applied as the first prognostic method. The results of the forecasting with the use of Winters' method were presented in Figure 8. The forecasting was conducted for twelve future periods. The variable fixed vector (Alfa $=0,814$; Delta=0,00; Gamma=0,00) was applied for the forecast.

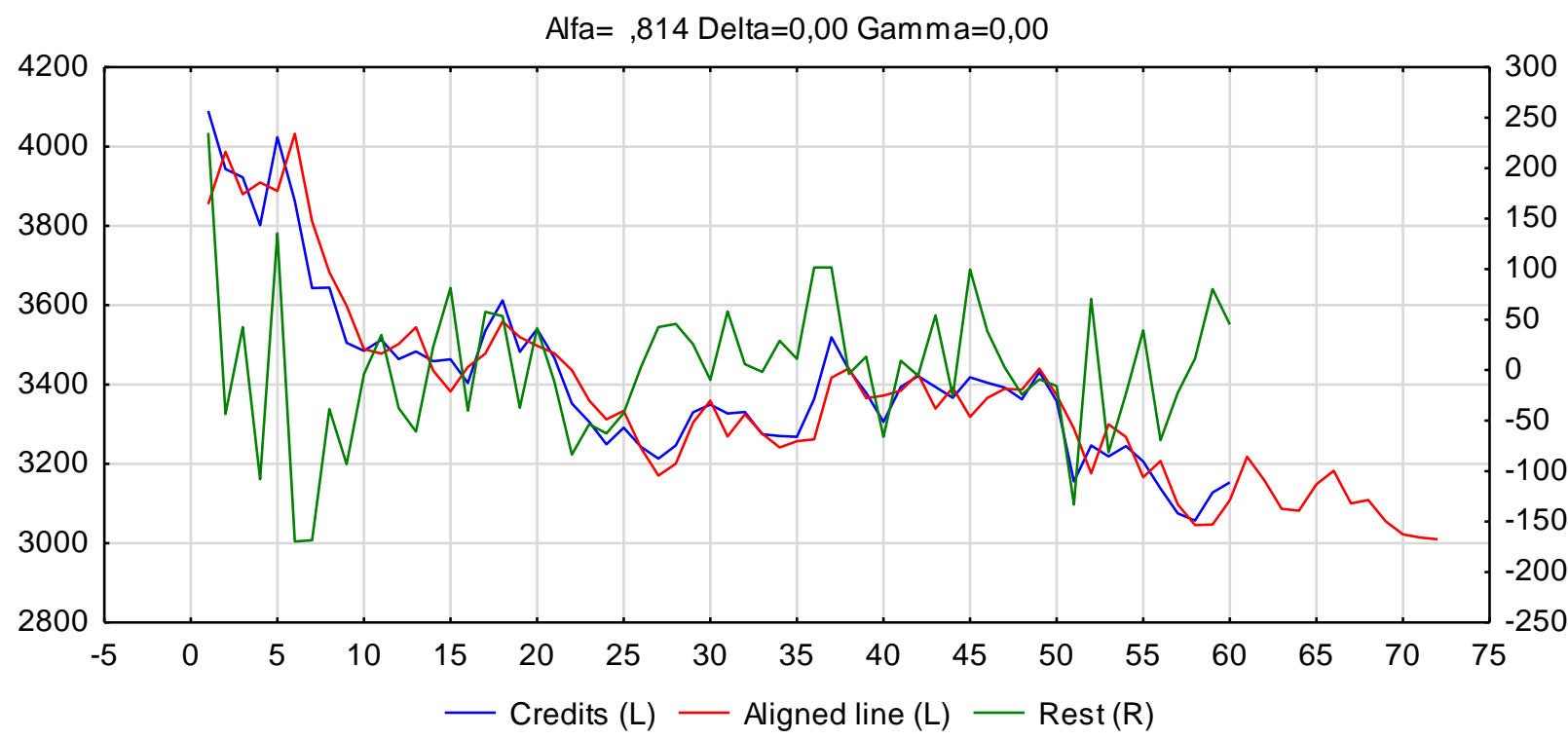

Figure 8. The forecasting, with Winters' method, of retrospective data concerning the amount of foreign currency loans in millions PLN granted to individual entrepreneurs between 2012 and 2016 for 2017 - 12 periods (months).

Source: own elaboration. 
The next step taken was the evaluation of the conducted forecasting in terms of the application of relative error of the forecasting, which equalled 3,46.

\begin{tabular}{c|r}
\hline \multirow{2}{*}{ Mean } & \\
\cline { 2 - 2 } & APE Wintersa \\
\hline & 3,46186141 \\
\hline
\end{tabular}

Figure 9. The application of relative error of the forecasting in order to evaluate the forecasting conducted with Winters' method.

Source: own elaboration.

Afterwards, the ARIMA model $(0,1,0)(0,0,1)$ was constructed for the forecasting of the selected time series comprised of 60 elements, and the forecasting was conducted for 12 future periods (Fig. 10).

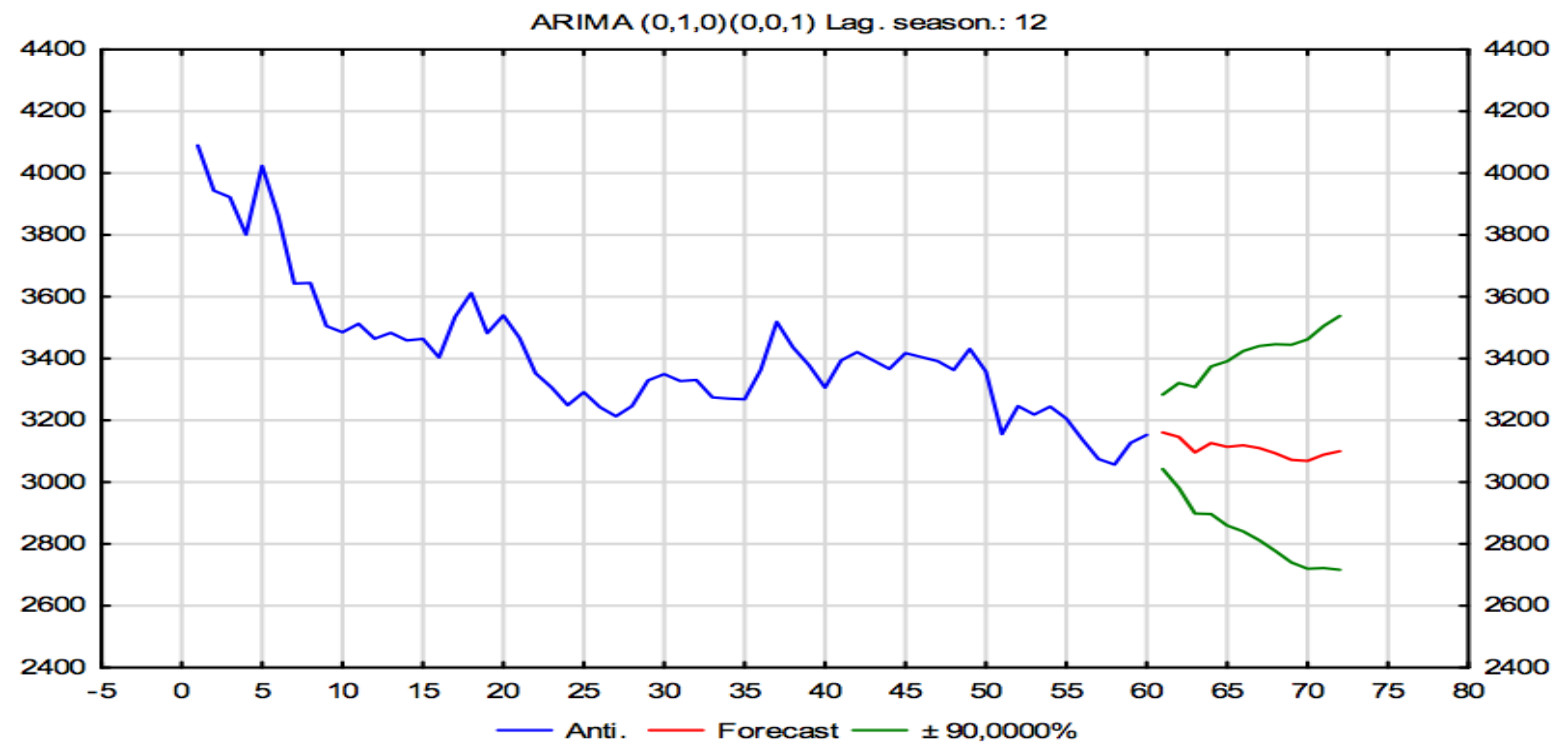

Figure 10. The forecasting, with the ARIMA model, of retrospective data concerning the amount of foreign currency loans in millions PLN granted to individual entrepreneurs between 2012 and 2016 for 2017 - 12 periods (months).

Source: own elaboration.

The subsequent stage of the research was the examination of relative error of the forecasting with the application of the ARIMA model. The relative error of the forecasting was as follows: 3,94 (Fig. 11).

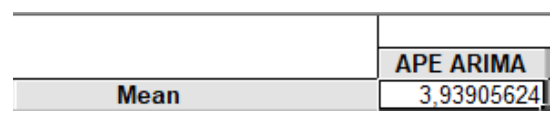

Figure 11. The application of relative error of the forecasting in order to evaluate the forecasting conducted with the ARIMA model.

Source: own elaboration. 


\section{4. $\quad$ Forecasting}

The evaluation of the conducted forecasting proves that Winters' exponential smoothing method appeared to be the best one, since the relative error of the forecasting was the lowest, equalling 3,64. In conclusion, the above-mentioned method will be applied in order to forecast the original time series. The forecasting was conducted with variable fixed vector Alfa=0,754., Delta=0,00., Gamma=0,00. For 12 future periods (Fig. 12).

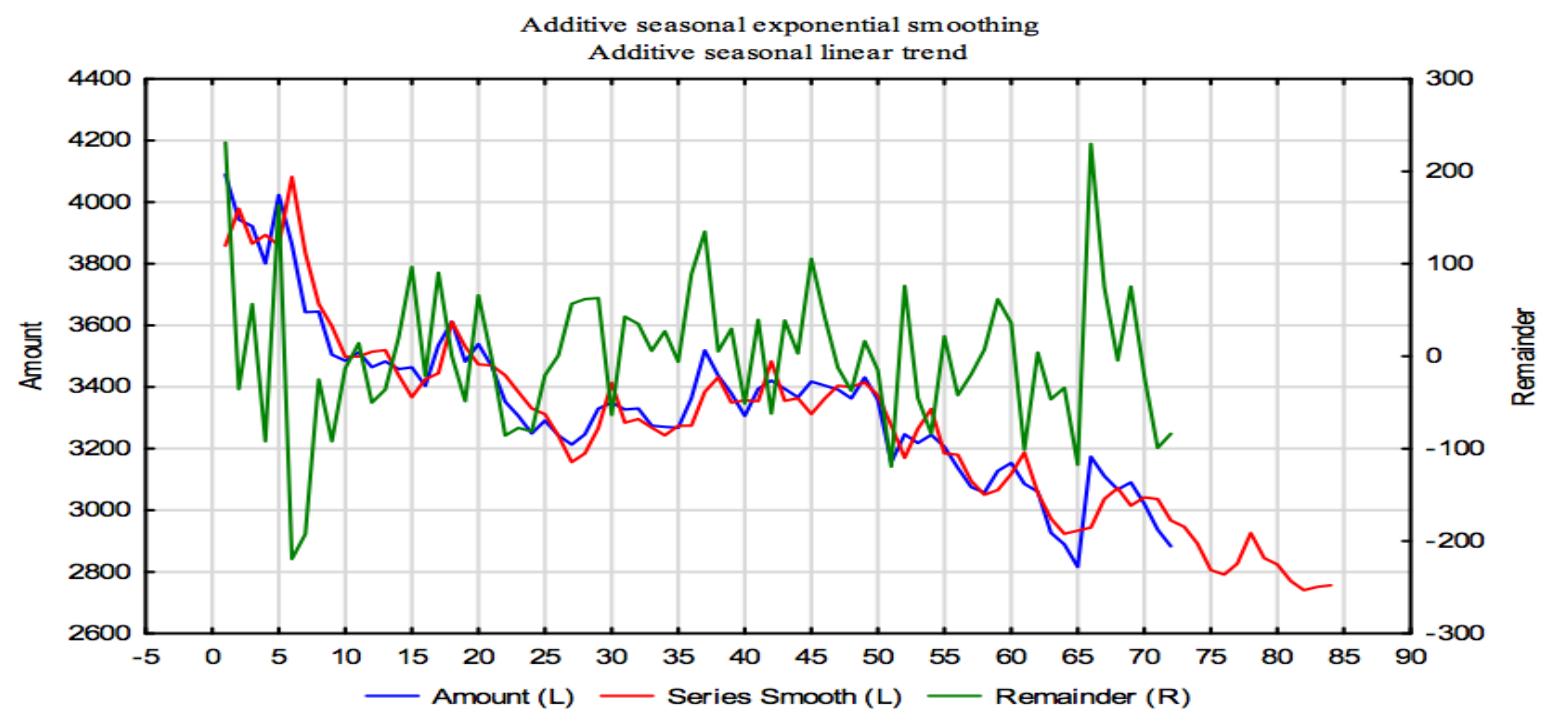

Figure 12. The forecasting, with Winters' method, of retrospective data concerning the amount of foreign currency loans in millions PLN granted to individual entrepreneurs between 2012 and 2017 for 2018 - 12 periods (months).

Source: own elaboration.

The conducted forecasting was analyzed and evaluated in terms of the analysis and evaluation of the remainder of the constructed model. 

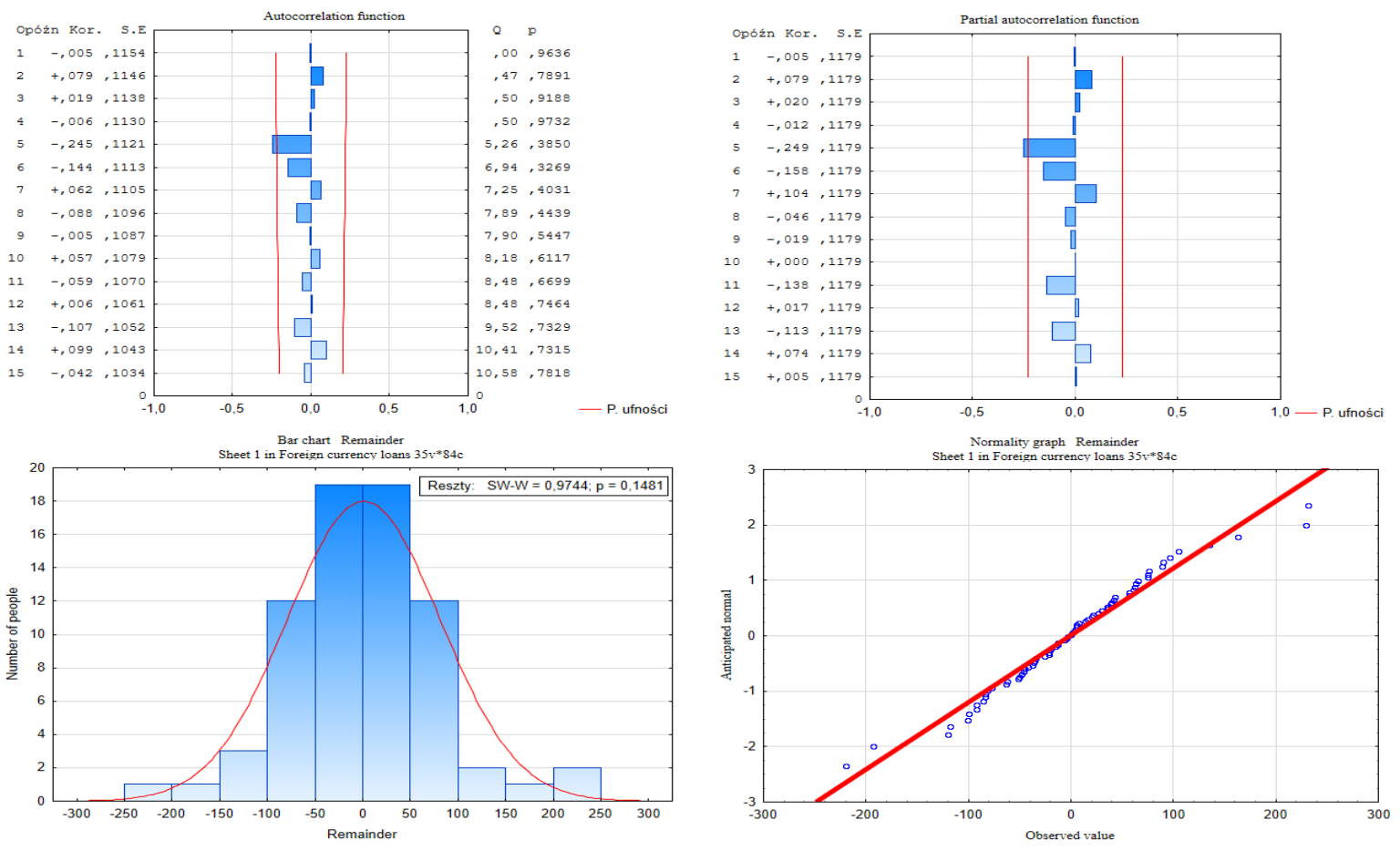

Figure 13. Evaluation of the remainder of the Winters' constructed model with the application of research tools such as: autocorrelation, partial autocorrelation, normality graph, bar chart and Shapiro-Wilk test.

Source: own elaboration.

In Figure 13, the goodness-of-fit Q test indicates that the remainders are uncorrelated (testing $\mathrm{p}$ equals $0,7818>0,05$ (autocorrelation). Additionally, it is worth mentioning that in case of the observation of partial autocorrelation, the values of this function are statistically irrelevant. This strengthens the conviction that the remainders constitute white noise. The outlined bar chart indicates that the remainders have a distribution similar to a normal one, and the normality graph confirms that almost all quantiles for the remainder are placed along the straight line corresponding to a normal distribution. Hence, there is an underlying presumption that white noise in the constructed model has a normal distribution. Thus, it was recognized that the constructed model is accurate.

\section{Summary and conclusions}

The conducted analysis and evaluation of time series of data concerning the amount of foreign currency loans in millions PLN granted to individual entrepreneurs between 2012 and 2017 on a monthly basis indicates, generally, the existence of a declining trend.

As a result of the research conducted, the answer to the main research question justifies the performance of the analysis and evaluation of time series of data concerning the amount of foreign currency loans in millions PLN granted to individual entrepreneurs 
between 2012 and 2017 on a monthly basis in order to choose the appropriate prognostic method and conduct the forecasting.

The detailed results of the forecasting of time series concerning the amount of foreign currency loans in millions PLN granted to individual entrepreneurs between 2012 and 2017 on a monthly basis comprised of 72 elements for 12 future periods with Winters' method are presented in table 1.

Table 1. Results of the forecasting with Winters' method on the basis of the data concerning the amount of foreign currency loans in millions PLN granted to individual entrepreneurs between 2012 and 2017 on a monthly basis comprised of 72 elements for 12 future periods.

\begin{tabular}{|c|c|c|}
\hline No & Month & $\begin{array}{c}\text { The forecast of the amount of foreign currency loans granted for } \\
\text { individual entrepreneurs with the Winters' method for 2018 in } \\
\text { millions PLN }\end{array}$ \\
\hline 1 & January & 2946,30 \\
\hline 2 & February & 2892,15 \\
\hline 3 & March & 2805,84 \\
\hline 4 & April & 2791,14 \\
\hline 5 & May & 2826,93 \\
\hline 6 & June & 2925,75 \\
\hline 7 & July & 2844,73 \\
\hline 8 & August & 2824,03 \\
\hline 9 & September & 2770,60 \\
\hline 10 & October & 2740,84 \\
\hline 11 & November & 2751,15 \\
\hline 12 & December & 2756,32 \\
\hline
\end{tabular}

Source: own elaboration.

The application of Winters' method, with relationships within the selected time series concerning the amount of foreign currency loans having been observed, can improve the planning of funds allowed for loan drawing from institutions such as banks in the aspects of economic security. 


\section{References:}

1. Araten, M et al. (2004) 'Measuring LGD on commercial loans: an 18-year internal study', The RMA Journal, 86 (8) (2004), 96-103.

2. Asarnow, E. \& Edwards, D. (1995) 'Measuring loss on defaulted bank loans: A 24-year study', The Journal of Commercial Lending, 77 (7) (1995), pp. 11-23.

3. Coenen, G., Adam, P., Straub, R. (2008) 'Tax reform and labour-market performance in the euro area: a simulation-based analysis using the new area-wide model', Journal of Economic Dynamics and Control, 32 (8) (2008), pp. 2543-2583.

4. Dell'Ariccia, G., et. al. (2016) 'Credit booms and macrofinancial stability', Economic Policy, 31 (86) (2016), pp. 299-355.

5. Devereux, M. B., Sutherland, A. (2011) 'Country portfolios in open economy macro models', The Journal of the European Economic Association, 9 (2) (2011), pp. 337-369.

6. Devereux, M. B., Yetman, J. (2010) 'Leverage constraints and the international transmission of shocks', The Journal of Money, Credit and Banking, 42 (S1) (2010), pp. 71-105.

7. Dhyne E., et. al. (2006) 'Price changes in the euro area and the united states: some facts from individual consumer price data', Journal of Economic Perspectives, 20 (2) (2006), pp. 171-192.

8. Dübel, H. J., Walley, S. (2010) 'Regulation of foreign currency mortgage loans: the case of transition countries in central and eastern Europe', World Bank Other Operational Studies 12943, The World Bank (2010).

9. Egert, B., Backe, P., Zumer, T. (2007) 'Private-sector credit in central and eastern europe: new (over)shooting stars?', Comparative Economic Studies., 49 (2) (2007), pp. 201-231.

10. Elekdag, S., Tchakarov, I. (2007) 'Balance sheets, exchange rate policy, and welfare', Journal of Economic Dynamics and Control, 31 (12) (2007), pp. 3986-4015.

11. Elenev, V., Landvoigt T., Van Nieuwerburgh, S. (2016) 'Phasing out the GSEs', The Journal of Monetary Economics., 81 (C) (2016), pp. 111-132.

12. Nurzyńska, A. (2016) Security of services in international air transport of passenger transport. Wydawnictwo Naukowe SOPHIA.

13. Redo, M., Wójtowicz, K., Ciak, M. J. (2018) Bezpieczeństwo finansów publicznych. $\mathrm{CeDeWu}$. 
14. Rubio, M., Carrasco-Gallego, J. A. (2014) 'Macroprudential and monetary policies: implications for financial stability and welfare', The Journal of Banking and Finance, 49 (2014), pp. 326-336.

15. Ruge-Murcia, F. (2012) 'Estimating nonlinear DSGE models by the simulated method of moments: with an application to business cycles', Journal of Economic Dynamics and Control, 36 (6) (2012), pp. 914-938. 